Creative Commons User License: CC BY-NC-ND

Abstracted by: EBSCOhost, Electronic Journals Service (EJS),

Google Scholar, Journal Seek, Scientific Commons,

Food and Agricultural Organization (FAO), CABI and Scopus

http://eoi.citefactor.org/10.11226/v25i4
Journal of Agricultural Extension

Vol. 25 (4) October, 2021

ISSN(e): 24086851; ISSN(Print); 1119944X

http://journal.aesonnigeria.org

http://www.ajol.info/index.php/jae

Email: editorinchief@aesonnigeria.org

\title{
Factors Affecting Multiple Climate Change Adaptation Practices of Smallholder Farmers in lower Eastern Kenya
}

https://dx.doi.org/10.4314/jae.v25i4.10

\section{Hezron R. Mogaka}

Department of Agricultural Economics and Extension, University of Embu, Embu, Kenya

Email: hezronmogaka@gmail.com, Phone: +254738881188

\section{Lydia N. Muriithi}

Department of Agricultural Resource Management, University of Embu, Embu, Kenya

Email: muriithilydia03@gmail.com,Phone: +254706194846

\section{Abstract}

The study investigated the socioeconomic and institutional factors influencing uptake of multiple climate change adaptation practices among smallholder farmers in lower Eastern Kenya. Multistage sampling procedure was used to select 384 small-scale farmers. Percentage and regression were used in the analysis. Among the socio-economic factors, gender positively and significantly influenced adoption of conservation agriculture and water harvesting at 5\%, respectively. Among the institutional factors, distance to markets positively or negatively influenced uptake of all the technologies at $1 \%$ and $5 \%$, respectively. Due to complementarity in adoption of all the seven adaptation practices, age and distance to nearest markets should be considered during technology dissemination. The study, therefore, calls for agricultural policy reforms that aim at designing incentive programmes which adequately address most of the socioeconomic and institutional issues related to uptake of adaptation practices as well as encouraging off-farm diversification.

Keywords: Adoption, agricultural technologies; smallholder farmers

\section{Introduction}

Climate change and agriculture are intricately interlinked (Chandio, Ozturk, Akram, Ahmad, and Mirani, 2020). Increasing temperatures, erratic rainfalls and frequent and more severe droughts threaten food security in agriculturally based economies. On the other hand, different farming practices affect climate change through emission of greenhouse gases (GHGs). The impacts have been detrimental to agricultural dependent countries, primarily those in tropical Africa (Woods, Nielsen, Pedersen, and Kristofersson, 2017). According to Awazi, and Tchamba (2019), GHGs account for $7 \%$ of the total world's emissions, implying a higher regional burden concerning climate change impacts.

Agriculture is the main sector of Kenyan economy. About $26 \%$ of the Kenya's Gross Domestic Product (GDP) is contributed directly and $27 \%$ indirectly through servicerelated sectors. Additionally, more than $50 \%$ of the total population have been 
Creative Commons User License: CC BY-NC-ND

Abstracted by: EBSCOhost, Electronic Journals Service (EJS), Google Scholar, Journal Seek, Scientific Commons,

Food and Agricultural Organization (FAO), CABI and Scopus
Journal of Agricultural Extension

Vol. 25 (4) October, 2021

ISSN(e): 24086851; ISSN(Print); 1119944X

http://journal.aesonnigeria.org

http://www.ajol.info/index.php/iae

Email: editorinchief@aesonnigeria.org

employed in various agricultural enterprises, with more than $70 \%$ residing in rural areas (Food and Agriculture Organization, 2018). Low productivity of small-scale mixed crop and livestock production has reduced the adaptive capacity in these regions due to high reliance on traditional practices, socioeconomic factors (age, gender, household size), poor complementary services like credit, marketing distance, poor infrastructure, extension and climatic factors (Mihiretu, Okoyo, and Lemma, 2019).

Smallholder farming in Kenya comprises small land sizes of less than or equal to 5 hectares on which food or one to two cash crops are grown using simple farm tools and relying on family labour (FAO, 2018). Climate change has increasingly become a challenge for smallholder farmers in lower Eastern Kenya due to high dependence on rain-fed agriculture (Abid, Scheffran, Schneider, and Elahi, 2019). On the other hand, limited access to technology, poor infrastructure increasing poverty and inappropriate agricultural related policies exacerbate the situation (Faling, 2020; Ling, Da, Shan, Yongzhi, and Chengcai, 2019). This has triggered much discussion on the need to increase agricultural productivity and sustainability in these regions but much less information is available on specific means to achieve this.

Climate change adaptation practices improve the efficiency of natural resources, build resilience of livelihoods and ecosystems and reduce greenhouse gases (GHGs) emissions. According to Amadu, McNamara, and Miller (2020), practices such as integration of crops, livestock and agroforestry systems, use of droughttolerant varieties, irrigation, water harvesting, crop insurance, crop rotation, intercropping, conservation agriculture (CA), weather agro-advisories, use of cover crops, and use climate information systems improve resiliency of vulnerable communities. Uptake of such practices results to higher earning, reduction in poverty, reduces staple food prices, improved nutritional status and increased employment opportunities. On the contrary, non-adopters can hardly maintain their marginal livelihood with socio-economic stagnation leading to deprivation (Kogo, Kumar, and Koech, 2020).

Many studies have been conducted on adoption processes and impacts of agricultural practices in developing countries (Takahashi, Muraoka, and Otsuka, 2020; Manda, Alene, Tufa, Abdoulaye, Wossen, Chikoye, and Manyong, 2019). In lower Eastern Kenya, adoption of agricultural technologies and innovations is still very slow, thus affecting productivity and livelihood (Muriithi, Onyari, Mogaka, Gichimu, Gatumo, and Kwena, 2021). Additionally, there appears to be a disconnect between developing climate change adaptation practices and farmers' willingness to adopt them due to issues like low uptake of on-station research recommendations or failure of researchers involving farming communities during the trial of the climate smart technologies. This reinforces the need to evaluate the specific factors hindering technology adoption among smallholder farmers. To bridge these gaps, the study evaluated the factors affecting multiple uptakes of climate change adaptation practices by smallholder farmers. Specifically, the study described the socio-economic and institutional factors influencing uptake of multiple climate change practices in lower Eastern Kenya. 
Creative Commons User License: CC BY-NC-ND

Abstracted by: EBSCOhost, Electronic Journals Service (EJS),

Google Scholar, Journal Seek, Scientific Commons,

Food and Agricultural Organization (FAO), CABI and Scopus
Journal of Agricultural Extension

Vol. 25 (4) October, 2021

ISSN(e): 24086851; ISSN(Print); 1119944X

http://journal.aesonnigeria.org

http://www.ajol.info/index.php/jae

Email: editorinchief@aesonnigeria.org

\section{Methodology}

The study was conducted in lower Eastern Kenya. It lies between longitude 364' and $39^{\circ} 0^{\prime}$ east and latitude $0^{\circ} 10^{\prime}$ and $3^{\circ} 0^{\prime}$ south. The region covers an area of $65,775 \mathrm{~km}^{2}$ with a population of about 2,105,493 (Kenya National Bureau of Statistics, 2019). The region has a semi-arid climate, with most residents engaging in small scale farming and agro-pastoralism. Multistage sampling method was used in selecting smallholder farmers in three counties, that is, Machakos, Makueni and Kitui. The procedure involved a combination of more than two sampling procedures. Stage one involved selection of two sub-counties randomly from each of the counties (Kathiani, Kangundo; Kibwezi West, Makueni; Kitui South, Mwingi West). In the second stage, six wards were randomly chosen from the selected sub-counties (Mua, Kangundo North; Kathonzweni, Makindu; Mutomo and Mui). Thirdly, random sampling of 384 households to be interviewed was done using a sampling frame obtained from the ward administrators. Similarly, adaptation practices had been disseminated by Kenya Agricultural and Livestock Research Organisation (KALROKatumani) in collaboration with the Kenya Meteorological Department (KMD) through radio, television and public meetings.

An open data kit (ODK) application was used to design a semi-structured questionnaire. Pretesting of the questionnaire was conducted using 30 farmers selected randomly from the study areas. Necessary modifications were made before administering it to 384 respondents. Using STATA version 13, descriptive statistics and a multivariate probit model were used in analysis and presentation of the collected data. The seven categories of agricultural practices considered included; integrated farming system, intercropping, crop rotation, conservation agriculture, agroforestry, crop diversification and water harvesting.

Following Bedeke, Vanhove, Gezahegn, Natarajan, and Van Damme, (2019), a Multivariate Probit (MVP) model which recognizes correlation in the choice to adopt several adaptation strategies simultaneously was then applied as follows;

$y_{i j m}^{*}=X_{i j m} \beta_{m}+\varepsilon_{i j m}$

Where $\left(y_{i j m}^{*}\right)=$ level of expected benefit, $(i)=$ household id, $(m)=$ type of adaptation strategy, $\left(X_{i j m}\right)=$ vector of explanatory variables, $\left(\beta_{m}\right)=$ vector of unknown parameters and $\left(\varepsilon_{i j m}\right)=$ normally distributed error terms.

\section{Results and Discussions}

\section{Smallholder Farmers' Perception on Climate change}

Result in Table 1 shows that a good number of the farmers (42.60\%) reported to have noticed early on-set of rains, followed by high temperatures $(22.06 \%)$, excessive drought conditions (11.63\%), unusually long rainfall periods $(11.15 \%)$, excessive cloudy periods (6.64\%) and low temperatures $(5.93 \%)$ This illustrates that climate change is evident in the three counties, necessitating the need to adopt 
Creative Commons User License: CC BY-NC-ND

Abstracted by: EBSCOhost, Electronic Journals Service (EJS),

Google Scholar, Journal Seek, Scientific Commons,

Food and Agricultural Organization (FAO), CABI and Scopus

http://eoi.citefactor.org/10.11226/v25i4
Journal of Agricultural Extension

Vol. 25 (4) October, 2021

ISSN(e): 24086851; ISSN(Print); 1119944X

http://journal.aesonnigeria.org

http://www.ajol.info/index.php/jae

Email: editorinchief@aesonnigeria.org

various technologies as a way of increasing resilience. These results coincide with the findings of Gladys (2017), who reported temperature and rainfall variability as the major effects on food production due to low adoption of modern technologies.

Table 1. Major climatic changes observed in the three counties

\begin{tabular}{lc}
\hline Variable & Percent (\%) \\
\hline Early rains & 42.60 \\
Long rainfall & 11.15 \\
High/extreme temperatures & 22.06 \\
Low temperatures & 5.93 \\
Excessive drought conditions & 11.63 \\
Excessive cloudy periods & 6.64 \\
\hline
\end{tabular}

\section{Field survey, 2021}

\section{Climate Change Practices Adopted by Smallholder Farmers}

The results in Table 2 reveal that about $23 \%$ of the respondents practiced integrated farming system, followed by intercropping (16.88\%), crop rotation (15.09\%), agroforestry (12.82\%) and conservation agriculture (11.99\%). About $10 \%$ and $9.79 \%$ of the farmers adopted crop diversification and water harvesting respectively. The finding is consistent with that of (Mujeyi, Mudhara, and Mutenje, 2020), who mentioned that a farmer's choice for the climate practice(s) to adopt may be influenced by other factors such as convenience or ease of adoption, performance by early adopters or socio-economic considerations.

\section{Table 2. Climate change practices adapted by smallholder farmers}

\begin{tabular}{lc}
\hline Agricultural technology & Percent (\%) \\
\hline Integrated farming system & 23.36 \\
Intercropping & 16.88 \\
Crop rotation & 15.09 \\
Conservation agriculture & 11.99 \\
Crop diversification & 10.06 \\
Water harvesting & 9.79 \\
Agroforestry & 12.82 \\
\hline
\end{tabular}

${ }^{*}$ Multiple responses

\section{Determinants of Multiple Climate Change Adaptation Practices}

Table 3 shows that farmers age was significant and negatively reduced adoption of integrated farming system, intercropping and agroforestry, while it increased adoption of crop rotation, conservation agriculture, crop diversification and water harvesting. Increased adoption of the technologies could be attributed to more knowledge and experience gained by older farmers over time and ability to evaluate technology information unlike younger farmers (Danso-Abbeam and Baiyegunhi,2017; Simtowe, Marenya, Amondo, Worku, and Erenstein, 2019). On contrary, low adoption of integrated farming system, intercropping and agroforestry could be explained by Chandio, and Jiang (2018), that as farmers grow older, there is an increase in risk aversion and a decreased interest in long term investments. 
Creative Commons User License: CC BY-NC-ND

Abstracted by: EBSCOhost, Electronic Journals Service (EJS), Google Scholar, Journal Seek, Scientific Commons,

Food and Agricultural Organization (FAO), CABI and Scopus

http://eoi.citefactor.org/10.11226/v25i4
Journal of Agricultural Extension

Vol. 25 (4) October, 2021

ISSN(e): 24086851; ISSN(Print); 1119944X

http://journal.aesonnigeria.org

http://www.ajol.info/index.php/iae

Email: editorinchief@aesonnigeria.org

Gender of the household head was positive and significant in adoption of crop rotation, conservation agriculture, crop diversification and water harvesting (Table 3),

Table 3: Factors influencing multiple climate change adaptation practices



Likelihood ratio test of $\mathrm{Rho}_{\mathrm{ij}}=0 ; \mathrm{Chi}^{2}(20)=148.78$; Prob $>\mathrm{Chi}=0.0000 ;{ }^{* * *},{ }^{\star *}$ and * show significance at $1 \%, 5 \%$ and $10 \%$ respectively.

indicating a higher likelihood of male farmers adopting it as compared to their counterpart female farmers. The result is consistent with that of Mulwa, Marenya, and Kassie (2017), who reported a positive and significant sex variable in improved agricultural technologies uptake. Additionally, the results showed that household education increased adoption of integrated farming system and conservation agriculture (Table 3). This means that attainment of higher educational status increases awareness about the benefits. A similar study by Donkoh, Azumah, and Awuni (2019), on adoption of multiple technologies by farmers in Ghana also reported education as an influence to farmers' decisions.

On the aspect of household size, there was a positive and significant impact on uptake of intercropping, agroforestry, crop diversification, and water harvesting, while low adoption was identified in Integrated farming system, crop rotation and conservation agriculture (Table 3). The justification on increased adoption could be 
Creative Commons User License: CC BY-NC-ND

Abstracted by: EBSCOhost, Electronic Journals Service (EJS), Google Scholar, Journal Seek, Scientific Commons,

Food and Agricultural Organization (FAO), CABI and Scopus
Journal of Agricultural Extension

Vol. 25 (4) October, 2021

ISSN(e): 24086851; ISSN(Print); 1119944X

http://journal.aesonnigeria.org

http://www.ajol.info/index.php/jae

Email: editorinchief@aesonnigeria.org

availability of necessary labor within large households. In previous studies by Simtowe et al., 2019 and Mulwa et al., 2017, some correlations between adoption of improved technologies and household size have been established. Moreover, offfarm employment was positive and significant in adoption of conservation agriculture

and water harvesting. As reported by Morris, Henley, and Dowell, (2017), having diversified income-generating sources enhances farmers' capacity to purchase improved agricultural technologies.

Size of farm cultivated negatively and significantly reduced adoption of integrated farming system, conservation agriculture and agroforestry (Table 3). Meaning, farmers cultivating large farms had a lower probability to adopt a tree nursery unlike those with smaller farm sizes due to the extra cost of ploughing and seeds. This result is affirming the finding of García, Gaspart, Kastner, and Meyfroidt (2020), that during adoption of improved technologies, scarcity of land could induce agricultural intensification. However, there was an increased adoption of intercropping, crop diversification and water harvesting (Table 5). The finding relates to the study of Danso-Abbeam and Baiyegunhi (2017), that farm size to be significant and positively affect adoption of improved technologies.

Distance to the nearest market was significant and had a negative relationship with all the technologies except integrated farming system and water harvesting (Table $3)$. The probable reason for the negative relationship is that poor infrastructure lessens farmers ability to supply goods to the markets using different technologies. Conversely, the positive relationship could signify less opportunity cost in adapting labour-intensive practices among rural households. In favour of the finding, argument by Amare, and Simane (2017), reveals high willingness of rural households taking up adaptation in order to reduce climate related risks due to availability of less incomeearning opportunities.

Furthermore, access to credit facilities increased adoption of conservation agriculture and crop diversification (Table 3 ). The credit facilities might encourage farmer participation in cooperative action or additional investments related to agricultural production. The result relates with Asante-Addo et al. 2017 and Mustapha, Mohammed, and Abukari (2017), who noticed that, a farmer's purchasing power enables use of improved seeds hence positively impacting degree of market participation. The finding, however, contradicts studies by Ojo, Baiyegunhi, and Salami, (2019) and Wongnaa, Awunyo-Vitor, and Bakang (2018), who illustrated that inadequate access to farm credit impedes the adoption of improved technologies by farmers.

Agricultural extension contacts are positively correlated with crop rotation, conservation agriculture and water harvesting (Table 3). It is expected that farmers access to extension agents increases technical flow of agricultural information.

Contrary to our expectation, a negative correlation with integrated farming system was identified, contradicting the findings of Amikuzuno (2015), and Chandio and 
Creative Commons User License: CC BY-NC-ND

Abstracted by: EBSCOhost, Electronic Journals Service (EJS), Google Scholar, Journal Seek, Scientific Commons,

Food and Agricultural Organization (FAO), CABI and Scopus
Journal of Agricultural Extension

Vol. 25 (4) October, 2021

ISSN(e): 24086851; ISSN(Print); 1119944X

http://journal.aesonnigeria.org

http://www.ajol.info/index.php/jae

Email: editorinchief@aesonnigeria.org

Jiang, (2020). May be, extension agents in these Counties do not provide information on the selected improved technologies to smallholder farmers. In addition, ownership of title deeds positively increased adoption of crop rotation and crop diversification (Table 3). This implies that farmers owning land had the right to use and are likely to use productivity-enhancing practices and at the same time reducing climate risks. The finding relates to a study by Brüssow, Faße, and Grote (2017), in Tanzania that revealed a significant correlation between plot tenure security and drought-resistant crop variety adoption.

\section{Conclusion and Recommendations}

Variables affecting decisions to adopt a technology differ among technologies. The probability of adopting a specific adaptation strategy significantly decreases with adoption of another adaptation strategy, suggesting substitutability effects. In some cases, probability of adopting a specific technology increased significantly with adoption of another adaptation strategy, indicating complementarity.

During design of incentive programmes for multiple adoption of agricultural technologies by smallholder farmers, policy makers should consider several socioeconomic and institutional factors to ensure maximization, for instance, provision of more training programmes on climate smart practices benefits to soil properties. Also, there is need to foster credit markets for easy accessibility and affordability by farmers. Finally, off-farm diversification should be encouraged through access to relevant market information by the farmers so as to lower opportunity costs of resource allocation and on-farm labour.

\section{Acknowledgement}

This research was supported by International Development Research Centre (IDRC) through the project Climate Change Adaptation and ICT (CHAI).

\section{Reference}

Abid, M., Scheffran, J., Schneider, U. A., \& Elahi, E. (2019). Farmer perceptions of climate change, observed trends and adaptation of agriculture in Pakistan. Environmental Management, 63(1),110-123. https://doi. org/10.1007/s00267-018-1113-7

Amare, A., \& Simane, B. (2017). Determinants of smallholder farmers' decision to adopt adaptation options to climate change and variability in the Muger Sub basin of the Upper Blue Nile basin of Ethiopia. Agriculture \& food security, 6(1),1-20.

Asante-Addo, C., Mockshell, J., Zeller, M., Siddig, K., \& Egyir, I. S. (2017). Agricultural credit provision: what really determines farmers' participation and credit rationing?. Agricultural Finance Review.

Awazi, N. P., \& Tchamba, M. N. (2019). Enhancing agricultural sustainability and productivity under changing climate conditions through improved agroforestry practices in smallholder farming systems in sub-Saharan Africa. African Journal of Agricultural Research, 14(7), 379-388.

Bedeke, S., W. Vanhove, M. Gezahegn, K. Natarajan, and Van Damme, P.. (2019). "Adoption of climate change adaptation strategies by maize-dependent smallholders in Ethiopia." NJAS - Wageningen Journal of Life Sciences, 88: 96-104. 
Creative Commons User License: CC BY-NC-ND

Abstracted by: EBSCOhost, Electronic Journals Service (EJS), Google Scholar, Journal Seek, Scientific Commons,

Food and Agricultural Organization (FAO), CABI and Scopus

http://eoi.citefactor.org/10.11226/v25i4
Journal of Agricultural Extension

Vol. 25 (4) October, 2021

ISSN(e): 24086851; ISSN(Print); 1119944X

http://journal.aesonnigeria.org

http://www.ajol.info/index.php/iae

Email: editorinchief@aesonnigeria.org

Brüssow, K., Faße, A., \& Grote, U. (2017). Implications of climate-smart strategy adoption by farm households for food security in Tanzania. Food security, 9(6):1203-1218.

Chandio, A. A., \& Jiang, Y. (2018). Determinants of Credit Constraints: Evidence from Sindh, Pakistan. Emerging Markets Finance and Trade, 54(15):3401-3410.

Chandio, A. A., Ozturk, I., Akram, W., Ahmad, F., \& Mirani, A. A. (2020). Empirical analysis of climate change factors affecting cereal yield: Evidence from Turkey. Environmental Science and Pollution Research, 27(11):11944-11957.

Danso-Abbeam, G., \& Baiyegunhi, L. J. (2017). Adoption of agrochemical management practices among smallholder cocoa farmers in Ghana. African Journal of Science, Technology, Innovation and Development, 9(6):717-728.

Donkoh, S. A., Azumah, S. B., \& Awuni, J. A. (2019). Adoption of improved agricultural technologies among rice farmers in Ghana: a multivariate probit approach. Ghana Journal of Development Studies, 16(1):46-67.

Faling, M. (2020). Framing agriculture and climate in Kenyan policies: A longitudinal perspective. Environmental Science \& Policy, 106(1): 228-239.

FAO (Food and Agriculture Organization). (2018). Climate Change and Food Security: A Framework Document. Rome, Italy.

García, V. R., Gaspart, F., Kastner, T., \& Meyfroidt, P. (2020). Agricultural intensification and land use change: assessing country-level induced intensification, land sparing and rebound effect. Environmental Research Letters, 15(8): 6-8.

Gladys, K. V. (2017). Rainfall and temperature variability and its effect on food security in Kitui county, Kenya. International Journal of Development and Sustainability, 6(8):924-939.

Kenya National Bureau of Statistics (KNBS) (). (2019). Population by County and SubCounty. Volume 1. KNBS, Nairobi.

Kogo, B. K., Kumar, L., \& Koech, R. (2020). Climate change and variability in Kenya: a review of impacts on agriculture and food security. Environment, Development and Sustainability, 1-21.

Manda, J., Alene, A. D., Tufa, A. H., Abdoulaye, T., Wossen, T., Chikoye, D., \& Manyong, V. (2019). The poverty impacts of improved cowpea varieties in Nigeria: A counterfactual analysis. World Development, 122:261-271.

Morris, W., Henley, A., \& Dowell, D. (2017). Farm diversification, entrepreneurship and technology adoption: Analysis of upland farmers in Wales. Journal of Rural Studies, 53:132-143.

Mulwa, C., Marenya, P., \& Kassie, M. (2017). Response to climate risks among smallholder farmers in Malawi: A multivariate probit assessment of the role of information, household demographics, and farm characteristics. Climate Risk Management, 16:208-221.

Mihiretu, A., Okoyo, E. N., \& Lemma, T. (2019). Determinants of adaptation choices to climate change in agro-pastoral dry lands of Northeastern Amhara, Ethiopia. Cogent Environmental Science, 5(1):5-9.

Mujeyi, A., Mudhara, M., \& Mutenje, M. J. (2020). Adoption determinants of multiple climate smart agricultural technologies in Zimbabwe: Considerations for scaling-up and out. African Journal of Science, Technology, Innovation and Development, 12(6):735746.

Mustapha, S., Mohammed, T., \& Abukari, I. (2017). Application of multinomial logistic to smallholder farmers' market participation in Northern Ghana. International Journal of Agricultural Economics, 2(3):55-62.

Ling, F., Da, C., Shan, G., Yongzhi, W., \& Chengcai, T. (2019). Responding to global warming: Mitigation policies and actions of stakeholders in China's tourism industry. 
Creative Commons User License: CC BY-NC-ND

Abstracted by: EBSCOhost, Electronic Journals Service (EJS), Google Scholar, Journal Seek, Scientific Commons,

Food and Agricultural Organization (FAO), CABI and Scopus
Journal of Agricultural Extension

Vol. 25 (4) October, 2021

ISSN(e): 24086851; ISSN(Print); $1119944 X$

http://journal.aesonnigeria.org

http://www.ajol.info/index.php/jae

Email: editorinchief@aesonnigeria.org

Journal of Resources and Ecology, 10(1):94-103. https://doi.org/10.5814/i.issn.1674764x.2019.01.012

Simtowe, F., Marenya, P., Amondo, E., Worku, M., \& Erenstein, O. (2019). Heterogeneous seed access and information exposure: implications for the adoption of droughttolerant maize varieties in Uganda. Agricultural and Food Economics, 7(1):1-23.

Takahashi, K., Muraoka, R., \& Otsuka, K. (2020). Technology adoption, impact, and extension in developing countries' agriculture: A review of the recent literature. Agricultural Economics, 51(1):31-45.

Wongnaa, C. A., Awunyo-Vitor, D., \& Bakang, J. E. A. (2018). Factors affecting adoption of Maize production technologies: A study in Ghana. Journal of Agricultural Sciences, 13(1):81-99.

Woods, B., Nielsen, H., Pedersen, A., \& Kristofersson, D. (2017). Farmer perceptions of climate change and responses in Danish agriculture. Land Use Policy, 65:109-120. 